\title{
DOSSIER | VERIFIC.AI APPLICATION: automated fact-checking in Brazilian 2018 general elections
}

Copyright (c) 2019 SBPjor / Associação Brasileira de Pesquisadores em Jornalismo
DARIO BRITO ROCHA JÚNIOR

Catholic University of Pernambuco, Recife - PE, Brazil ORCID: 0000-0002-1515-1720

ANTHONY JOSÉ DA CUNHA CARNEIRO LINS

Catholic University of Pernambuco, Recife - PE, Brazil ORCID: 0000-0002-7153-841X

ALICE CRISTINY FERREIRA DE SOUZA

Catholic University of Pernambuco, Recife - PE, Brazil ORCID: 0000-0002-8287-841X

LUIZ FELIPE DE OLIVEIRA LIBÓRIO

Federal University of Pernambuco, Recife - PE, Brazil ORCID: 0000-0001-8691-1195

ANDRÉ HENRIQUE DE BRITO LEITÃO

Catholic University of Pernambuco, Recife - PE, Brazil ORCID: 0000-0002-8372-0606

FLÁVIO HENRIQUE SOUZA SANTOS

Catholic University of Pernambuco, Recife - PE, Brazil

ORCID: 0000-0002-8438-080X

DOI: $10.25200 /$ BJR.v15n3.2019.1178

Received on: 20/02/2019| Approved on: 21/08/2019

\begin{abstract}
The increasingly hybrid relationship between consumption and production, the post-truth context, and the disinformation ecosystem have all caused tensions in journalism. Creating false news and spreading it across social networks has become common practice. This article introduces the development, testing and data analysis from the Verific.ai application prototype, an automated tool for checking news links on the Android operating system. This application uses data mining for defining the criteria for truthful and false news in the digital environment. The data are presented in the light of the descriptive exploratory analysis, based on tests conducted during the 2018 Brazilian elections. Through this it was
\end{abstract}


possible to define and apply criteria to quickly reveal any potentially false content, while also showing the type of online news content viewed unfavorably by the consuming public. Key words: Automated. Check. Disinformation. News. Elections.

\section{APLICATIVO VERIFIC.AI: automatização de checagem de notícias nas eleições brasileiras de 2018}

RESUMO - A relação mais híbrida entre consumo e produção, o contexto da pós-verdade e o ecossistema da desinformação provocaram tensões no jornalismo. Falsear a notícia tornou-se prática nas relações propagadas pelas redes sociais digitais. $\mathrm{O}$ artigo apresenta a experiência de desenvolvimento, teste e análise de dados do protótipo do aplicativo Verific. ai, uma ferramenta de automatização de checagem de links de notícias disponível para sistema Android. A plataforma aplica a técnica da mineração de dados a partir da definição de critérios de verdade e falsidade das notícias no ambiente digital. Os dados são apresentados à luz da análise exploratória descritiva, a partir de testes realizados no período eleitoral brasileiro de 2018. Mostrou-se como é possível delinear e aplicar critérios para evidenciação rápida de conteúdo com potencial falso, ao mesmo tempo em que se evidenciou que tipo de conteúdo tem sido colocado em xeque pelo público consumidor de notícias na internet. Palavras-chave: Automatização. Checagem. Desinformação. Notícias. Eleições.

\section{APLICACIÓN VERIFIC.AI: automatización de chequeo de noticias en las elecciones brasileñas de 2018}

RESUMEN - La relación más híbrida entre el consumo y la producción, el contexto de la postverdad y la ecosistema de la desinformación han provocado tensiones en el periodismo. Crear contenido falso se convirtió en práctica en la relaciones propagadas por las redes sociales digitales. El artículo presenta la experiencia de desarrollo, prueba y análisis de datos del prototipo de la aplicación Verific.ai, una herramienta de automatización de verificación de enlaces de noticias disponible para el sistema Android. La herramienta aplica la técnica de minería de datos definiendo criterios de verdad y falsedad de noticias en el digital. Los datos se presentan a la luz del análisis exploratorio-descriptivo, basado en pruebas realizadas en el período electoral brasileño de 2018 . Se ha probado que es posible definir y aplicar criterios de evaluación rápida de contenido con potencial falso, así como se ha mostrado el tipo de contenido que es cuestionado por el consumidor de noticias en la internet.

Palabras clave: Automatización. Chequeo. Desinformación. Noticias. Elecciones.

\section{Introduction}

The emergence of information and communication technologies has resulted in an increasingly hybrid relationship between consumption and production (Jenkins et al., 2014; Toffler, 2005). As Alvin Toffler (2005) explains, a new civilization has emerged as a result of this relationship, bringing with it "new family styles, 
different ways of working, loving and living; a new economy; new political conflicts; and, besides all this, an altered conscience" (Toffler, 2005, p.23). The shift from an economy based on the intensive use of capital and labor for mass production to an intellectual economy (Beck, 2000, 2002 as cited in Bendassolli et al., 2009) has resulted in a new code of behavior outstide the standardization, synchronization and centralization of power, information and energy (Toffler, 2005).

In the 21 st century, the network society described by Manuel Castells (2017) is organized around interconnected universes of digital communication, and collective intelligence (Lévy, 1998) projects our desire to participate in communication processes (Shirky, 2011). With the support of developing technologies, especially the computer, the internet and the web, information has become a strategic resource for the transformation of society, as explained by Daniel Bell (1977), generating more information, knowledge and devices.

This article is based on the new forms of online consumption of news and content due to the growing communication mediated by emotional online narratives. The resulting proposal aimed to develop a technical tool that could help internet users identify the accuracy of political information that circulated in Brazil during the 2018 election period. From this, we are able to look at establishing criteria that could facilitate and expedite the identification of false and truthful news circulating online.

This work is the result of applied research and details the design, development and testing of the Verific.ai platform - an automated news link checking tool for devices that run on the Android operating system. This tool is a cloud computing infrastructure developed in the Python programming language. This text presents an analysis of the data obtained from this tool conducted between the first and the second rounds of the 2018 Brazilian presidential elections - between the 16th and the 28th of October. Lastly, we address what we learned and the challenges resulting from the experience.

This work is based on the idea that knowledge is now the main force behind production (Kumar, 1997) and the internet, considered the first public media to have what Clay Shirky (2011) calls a post-Gutenburg economy, is the DNA of libertarian culture (Castells, 2003). This has caused a large-scale reproduction of a nonmediatized relationship with information (Lévy, 1999). The widespread connection and social, cultural, economic, and political reshaping of global networking (Lemos \& Lévy, 2010) has demassified the media 
by enabling information processing, selection, and retrieval to meet individual and specialized needs (Kumar, 1997).

At the same time, these new technologies have acted as an outlet for emotional narratives in the face of reason and the weakening of institutions (D'ancona, 2017). We have entered the era of post-truth, in which there is no longer just truth or lies. "Lying has essentially become a faultless trespass" (Keyes, 2018, p.17). This is why, in the midst of this change, there is a real need to appropriate technologies in an attempt to safeguard journalism, given the challenge posed by the post-truth era and the disinformation ecosystem (Wardle, 2017).

\section{Searching for the truth in disinformation}

The search for truth is an innate process in journalistic production, one of the basic principles and obligations of the profession (Kovach \& Rosentiel, 2003). The idea that news is a translation of a pure fact, a truth, or is a mirror for reality has been part of journalism ideology since the professionalization of newspapers (Alencar, 2010, as cited in Rodrigues \& Hennigen, 2011). In order for something to be considered news, it must be accurate, as Wilson Gomes explains (2009). In post-truth, however, the public is encouraged to doubt the existence of truth, to believe that truth and journalism are at odds with each other. The cyberculture described by Pierre Lévy (1999) amplifies strident questions and supports biased assimilations from the confirmation bias (D'ancona, 2017), leading the audience to distrust journalism's ability to escape error and deception.

As the new channels of information give the audience access to different versions of facts and multiple ways of narrating them (Alsina \& Cerqueira da Silva, 2018), the mass flow has a post-mass function (customizable and interactive). Information circulates in an open and shared manner, without the need for financial resources or concessions. The flow of communication is closer to conversation than to information, as explained by André Lemos and Pierre Lévy (2010).

This new communication system, its most powerful expressions being virtual communities on social networks, mediated by social, political and economic interests, creates a segmented society composed of an audience divided by ideologies, values, tastes, and lifestyles (Castells, 2017). Virtual communities, made up of mutual affinities and projects, explore new forms of 
public opinion. Citizens no longer restrict their point of view and access to information to the production of the mass media public sphere (Lemos \& Lévy, 2010). The time of choice and a collective mediation (idem) is done in real time, which gives the message itself a competitive nature (Castells, 2017).

Social networks, as tools that allow users to create individual profiles (Boyd \& Ellison, 2007 as cited in Recuero, 2012), become the eye of this ecosystem (Santaella, 2013). They amplify the production capacity and break mass communication paradigms, providing the audience with greater freedom. They are formed by fluid bonds, established according to the needs at the time, fostering a sensation of constant newness (Martino, 2015).

New technology has come at a time when there is increasing information and less meaning (D'ancona, 2017). Communication flows are now dominated by peer-to-peer interaction; not only does it generate news, it also generates rumors (idem), which makes it possible to spread speculations and lies in a matter of seconds (Kakutani, 2018). The shift from mass media to digital space is one of the reasons for having an environment that contains fragile information and that gave rise to so-called "Fake News" (Nielsen \& Graves, 2017). It is a diverse and widely spread field (Santaella, 2018) that adopts deliberately false political content, memes, or even misleading, but not completely false, messages.

Although the manufacturing of false news is nothing new to journalism or society (Firmo, 2018; Kakutani, 2018), in this scenario (where truth collapses, the potential for networking is amplified, information travels greater distances in record time, and the paradigms of mass communication have been broken) the ability to produce false information creates a new environment of disinformation.

The mirror of complexity for this scenario is both questioning the very validity of the term "Fake News" (Wardle, 2017) and the crusade in search of possible solutions, which finds the very difficulty of shaping consensus for the concept of truth (Nielsen \& Graves, 2017). So, developing mechanisms to prohibit, flag, or delete fake news reports in the digital environment is necessary (idem). There are two ways interventions can be effective: by promoting structural changes to prevent individuals from exposing false content or by enabling them to evaluate false news (Lazer et al., 2018).

In this regard, the fact-checking service, created more than 20 years ago (Zommer, 2015), began to spread as of the 2000 s. 
Fact-checking is now an international network (International FactChecking [IFCN], from the Poynter Institute) and, in Brazil, has gained strength during the period prior to the 2018 elections. In addition to the three IFCN signatory agencies - Lupa' Agency, Truco ${ }^{2}$ (Public Agency) and Aos Fatos ${ }^{3}$ - other services focusing on combating disinformation have been created which utilize activities distinct and/or complementary to fact-checking.

The fact-checking process is often laborious as it requires research and time to complete (Hassan et al., 2015). "Checking information in an unimaginably gigantic virtual space is a task that is ultimately too big for humans, however well meaning and diligent they are, consequently, it must end up being mechanized" (D'ancona, 2017, p. 107). Given the speed of circulation and the potential for spreading false news, and in the face of plutocratic, political and algorithmic power, the battle to defend the truth is a task that requires more and more actors, argues D'ancona (2017).

\section{Automated fact-checking and the holy grail of disinformation}

Faced with the spreading of false news, the union between journalism and computing might be a possible way to combat disinformation (Hassan et al., 2015). Automated checking programs began to spread, especially after the 2016 U.S. elections (Graves, 2018). The "holy grail" of this universe is the creation of a fully automatic fact-checking platform with the power to detect a statement in real time and be able to instantly classify it (Hassan et al., 2015), but this is not yet a reality.

Today, fact-checking automation (AFC) focuses on three overlapping goals: to identify false or questionable statements circulating online and in the media; to facilitate and assist the work of human verification; and deliver instant verification responses to the public (Graves, 2018). However, it has not yet overcome the challenge posed by ambiguities inherent in language (Ciampaglia et al., 2015). Much of the ground covered by human fact checkers requires a kind of judgment and sensitivity that cannot be reproduced by fully automated verification (Graves, 2018).

Automated fact-checking solutions are not attempts to eliminate the human role of identifying discourse and news, but are intended to assist this process by checkers, as well as offer faster ways 
to combat disinformation. Even though a fully automatic platform is the "grail", pursuing the larger goal and generating knowledge from real experiences can lead to not only increasingly accurate tools, but improved journalistic activity (idem).

\section{Verific.ai: in the 2018 Brazilian elections}

The aim of developing the AFC news link platform was: to discuss the establishment of criteria that can facilitate and expedite the identification of true and false news circulating online; to analyze the public's interest and purpose for using an automatic news checking platform; and to produce databases that assist Artificial Intelligence (Al) techniques for improving the natural language recognition process. Another objective was to build knowledge that in the future could serve to generate new and more sophisticated AFC products.

The Verific.ai tool is the result of an applied research and was tested during the second round of the 2018 Brazilian presidential elections. The platform is an application for Androidpowered digital devices, as well as a service for validating links using a cloud computing infrastructure developed in the Python programming language. The service is accessed via remote calls from the mobile app. Development took place between April and October 2018. The test took place between October 16 and 28, 2018. The data were analyzed between December 2018 and February 2019.

Through the theoretical contribution, the need to implement faster and more substantial techniques to assist the manual checking process became evident, as well as the need to offer internet users an automated verification experiences. So, a prototype was designed for a tool that could spontaneously receive news links and automatically submit them to a series of criteria that would give true value to news in the digital environment. The first stage of the work consisted of bibliographical research on the concepts of truth, post-truth and truth applied to journalism. Then, based on that research, we came up with a list of five criteria for validating or highlighting the false character of a news report through the links received. 


\subsection{Applied criteria}

The internet has broadened the range of typologies of information sources (Tomaél et al., 2009), which now include people, networks of people, software, communication portals, and others (Rodrigues \& Blattmann, 2011 as cited in Zattar, 2017). This breadth, considered from the perspective of post-truth and the disinformation ecosystem, requires "attitudes of information competence to develop skills that enable the understanding of the evaluation criteria of available information sources" (Zattar, 2017, p. 291).

Using the criteria to filter the content and present information in this medium increases the chances of avoiding circulating disinformation and reduces uncertainties in terms of reliability (Tomaél et al., 2009). Therefore, knowing how to differentiate information from disinformation means understanding what news is and how news is constructed, especially considering that the disinformation ecosystem encompasses at least seven different types of false news (Wardle, 2017) and those that cause the greatest concern are the ones that replicate the content form of news media, but not the organizational process or intention; it is made without complying to conventional editorial norms and processes of journalism (Lazer et al., 2018, p. 1094).

The news is a product linked to the professionalism movement of journalism, which comes from the separation of facts and opinions, and gave rise to the birth of the reporter and deontological codes between the nineteenth and twentieth century. To understand what news is and why it is the way it is, we need to understand the professional culture of the journalistic community, which during the nineteenth and twentieth centuries was shaped based on values such as the search for truth, objectivity and freedom (Traquina, 2005).

While providing reports of events regarding as being important seems simple enough, pursuing this goal has required a number of studies and materialized into a sequence of theories (idem), mainly through the understanding that news is historically inserted and "the definition of the news of an event or subject implies an outline of the contemporary understanding of the meaning of events as rules of human and institutional behavior" (Traquina, 2008, p. 95).

Journalistic language permeates the register of language, the communication process, ideological compromises, diverse subjects, 
and the rhetoric of journalism itself (Lage, 2006). Behind the glasses through which journalists see the world, there are a number of news values shared by members of the interpretive community of journalism (Traquina, 2008). This makes journalistic products more homogeneous than previously thought (Bourdieu, 1997 as cited in Traquina, 2008). There are rules that regulate the production and placement of reports, based on contextual and substantive criteria; the news values (idem).

Faced with the challenge posed by the rise of post-truth, synthesizing these rules and being able to apply them to the internet has been a task for media outlets and institutions. In 2016, Factcheck. org published a list of eight tips on how to spot fake news. The project recommended considering the source of the information, reading beyond the title, checking the author, what the support was, checking the date, checking whether it is satire, checking the biases when reading the information, and consulting fact-checking specialists. Similarly, the Vaza Falsiane! online course proposes a list of 10 topics to consider when trying to spot fake news and, just as Factcheck.org does, provides tips on how to identify the author and sources cited.

According to the examples, it is clear that identifying false news on the internet requires the use of quality criteria to evaluate sources of information, as proposed by Tomaél et al. (2009), criteria that adhere to the principles of what news is and how it is produced from a journalistic point of view, as in Table 1.

Table 1 - Criteria for evaluating the quality of sources (Tomaél et al., 2009).

\begin{tabular}{|l|l|}
\hline \multicolumn{1}{|c|}{ Criteria } & \multicolumn{1}{c|}{ Intention } \\
\hline Identifying information & $\begin{array}{l}\text { Detailed data to clearly identify the entity or } \\
\text { person responsible for the site. }\end{array}$ \\
\hline Consistency of information & Details and full information they provide. \\
\hline Trustworthy information & Check authority or the one responsible. \\
\hline Suitability of source & $\begin{array}{l}\text { Type of language used and coherence with } \\
\text { proposed objectives. }\end{array}$ \\
\hline Links & Clarity of links and existing pages they lead to. \\
\hline Ease of use & Easy to explore/navigate. \\
\hline Source layout & Media used. \\
\hline
\end{tabular}

Source: Evaluating sources of information on the internet: criteria of quality. Brapci, (2009). 
In order to measure the practicality of the effectiveness of these criteria, as well as to measure the technical ability to replicate them for automatic identification of false news circulating online, we decided to develop the Verific.ai platform and define a list of five criteria - based on the above-mentioned scheme and news values (Traquina, 2008). This list was entered as computational codes, where each criterion was attributed with a value on a scale of 1 to 10 , depending on the fulfillment of the base premise; and attributed an importance, on a scale from 1 to 9 , according to how relevant it was toward defining what is true or false news. Using the weighted average, we were able to present a final result to users, as shown in Figure 1.

Figure 1 - Formula for calculating the value/truth applied in the Verific.ai platform.

$$
V v=\frac{c_{1} * p_{1}+c_{2} * p_{2}+c_{3} * p_{3}+c_{4} * p_{4}+c_{5} * p_{5}}{\sum_{i=1}^{5} p_{i}}
$$

Source: prepared by author (2018).

The analysis determined that authority, currentness and predictability are basic objects for checking the quality of information on the internet; it is essential to identify who created it (Tomaél et al., 2004 as cited in Zattar, 2017), the author's reputation (Verg, 2010 as cited in Zattar, 2017), as well as the consistency of the sources used and other forms of information reliability (Tomaél et al., 2004 as cited in Zattar, 2017). Therefore, we applied criteria to determine whether the news appeared on other reliable (or unreliable) sites, whether certain graphics appeared in the title, whether the author actually exists, author publications, etc.

Two lists were made when producing the criteria. The first listed 30 reliable media outlets to be used for the purposes of this study, including sites from the country's 19 most-widely read newspapers, according to the National Newspaper Association (ANJ), four online national news portals, the website of a public communication vehicle, three foreign communication vehicles with websites and newsrooms in Brazil, and three vehicles which identify themselves as independent journalism.

The second list contained news portals and blogs that have published, at least once, some fake news, or have been identified as 
circulating disinformation on the web. Two search engines were used to put together this list: results of the researches elaborated by the group of the University of São Paulo, creator of the Online Political Debate Monitor, and the verifications performed by the agencies Aos Fatos and Lupa, in partnership with Facebook. A survey of the fake news identified by these two agencies was conducted between May and August 2018, and we then searched for sites that shared the same erroneous information.

\subsection{Data collection}

Verific.ai uses an information search engine whose interface is similar to that of Google - it has a search bar where the user pastes the link to be verified, selects a button below referring to the source of that information (blogs, social networks or websites) and clicks the check button, as illustrated in Figure 2. The software tool applies Data Mining to scan the web based on the previously defined criteria and highlight whether the link contains true or false content.

Figure 2 - Verific.ai operating sequence.

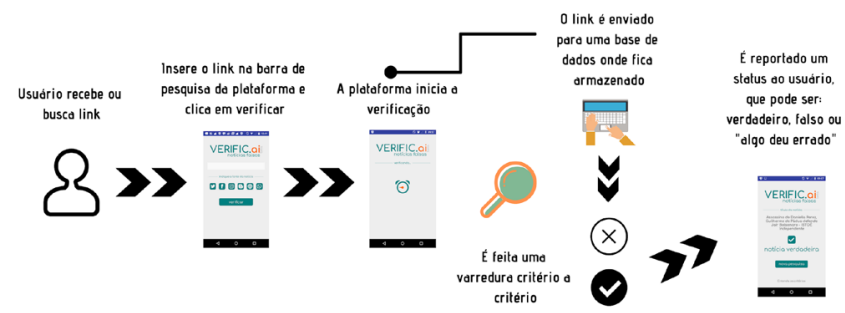

Source: prepared by author (2018).

Data mining is based on conceptual principles of exploratory data analysis and modeling (Cortes et al., 2002) the objective of which is "to explore and analyze data, by automatic or semi-automatic means, in large amounts of data, with the goal of discovering interesting rules or patterns" (Barry \& Linoff, 1997 as cited in Cortes et al., 2002, p. 1). Through data mining one is able to use reliable techniques to perform pattern recognition and generate expressive statistics (idem).

For this work, data mining is used to provide a descriptive analysis of what is discovered. The data analyzed below were 
collected automatically from the platform's dissemination on social networks and traditional media outlets.

\section{Results}

\subsection{People want to be helped!}

Up until October 28, 2018, the last day for capturing data, the platform had 269 individual user downloads across 271 different devices. An analysis of the graphs on the Google Play Console - a platform storage tool for developers - showed that the day which registered the most downloads per user and across devices was October 23, 2018. On this day alone, 70 downloads per user were performed across 69 devices, representing $26 \%$ of the total downloads performed during the testing period, as shown in Figure 3.

Figure 3 - Downloads per user, Android system, October $9-28,2018$.

Instalações por usuário por Versão do Android

ter, 9 de out de 2018 - dom, 28 de out de 2018

Instalaçōes por usuário - todas as versōes do Android

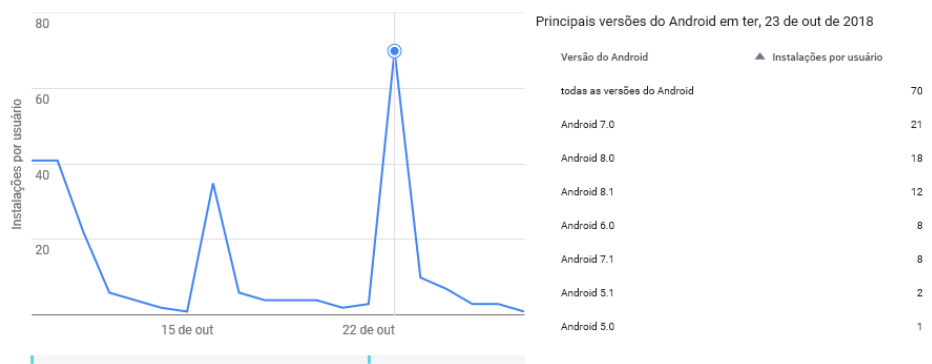

Source: Google Play Console (2019).

The date which registered the most downloads occurred on the same day a report was published about this application on Radio Jornal and on its website. Although the internet and social networks have grown as news consumption platforms, the websites and platforms of media outlets can be considered hubs for disseminating content online, as pointed out by Albert-László Barabási (Martino, 2014) which may be directly linked to this result. This is because the Radio Jornal website is linked to UOL, one of the most accessed news sites in the country. 


\subsection{Information consumption sources have multiplied!}

The Verific.ai platform received a total of 373 links to verify between October 16 and 28, 2018. These links were inserted automatically by web users in the media, on the university's portal and across social networks in late September and increased one week before data collection. Considering the twelve days of initial testing, Verific.ai maintained a daily average of 31 verified links.

The platform reported three types of results for all the links: "true news", "false news" and "something went wrong" (these were links that could not be checked by the platform and therefore had inconclusive results). Out of the 373 links, 39.4\% were fake news, 35.1\% true news, and $25.4 \%$ something went wrong. The links came from 94 different input channels, including news portals, blogs, social networks, sites connected to movements and political parties, and companies; this highlights the vast amount of information sources available on the internet and, at the same time, shows how fragmented the consumption of content is in this space in contrast to the hegemony of traditional media as access sources to information in the twentieth century.

Of these 94 different input channels, 65\% were news portals and $21 \%$ were links from social networks, a percentage that shows how much participation within the online information access ecosystem is credited to social networks. Although it has been growing year after year, the use of social media as a source of access to news has now begun to decline (Newman et al., 2018), and due to the amount of discussion around the disinformation circulating throughout this medium, it is clear that social networks are definitely active actors in discussions about current news production and consumption.

Out of the 94 links entered into Verific.ai, the site with the most entries was Facebook, followed by other traditional media information channels such as UOL, GI, Estadão, IstoÉ and the Folha de S. Paulo newspaper. These last two recorded the same number of entries as Twitter. Facebook alone accounted for $15.5 \%$ of all links, followed by UOL, with $11 \%$, and $G 1$ with $6 \%$ of the total uploads. Even though the use of Facebook for news consumption has dropped 17 percentage points in Brazil since 2016, the Reuters Institute Digital News Report 2018 reported that Facebook was the social network which generated the most entries for Verific.ai. Of the 80 digital social network links received, 72.5\% were from Facebook, 12.5\% from Twitter, 8.75\% from Instagram and 6.25\% from Youtube, as shown in Figure 4. 
Figure 4 - digital social network links received in Verific.ai platform.

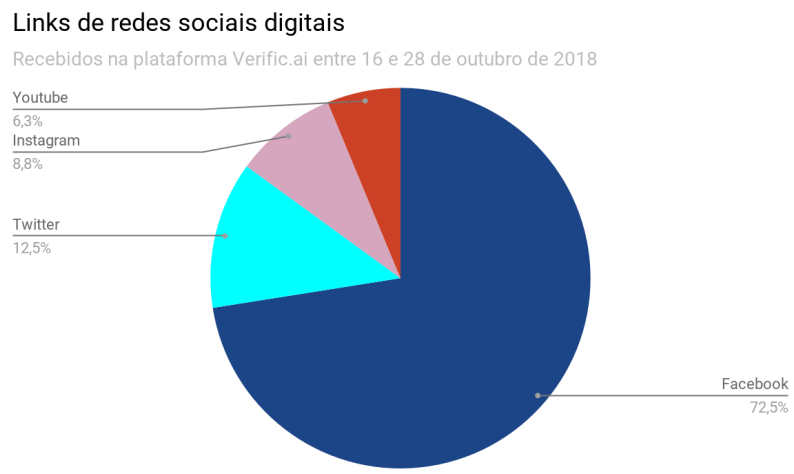

Source: prepared by author (2019).

\subsection{Politics generates content on social media!}

The fact-checking movement gained momentum in the United States in 2008, during the elections that resulted in then-candidate Barack Obama being elected to office (Neisser, 2015). The study The Spread of True and False News Online (2018), published in Science magazine, confirmed that it is within the sphere of politics that the impact of false news is felt the most. Therefore, the data obtained from the analysis of links received via digital social networks in the Verific.ai platform are considered relevant.

As Figure 5 illustrates, $55 \%$ of all links received by social networks contained information on the politics behind the 2018 Brazilian presidential election, while $42.5 \%$ were unavailable during the data analysis phase of this paper (which took place between December 2018 and February 2019), and the remaining 2.5\% addressed other topics, such as celebrities and events. The data confirms that politics was a topic which was present and mobilized on different social networks during the Brazilian electoral process, apart from the debates promoted by traditional media profiles and pages. Given the fact that fake political news has greater reach than other types of disinformation and that this kind of content circulates across social networks on nonjournalistic platforms, means it is necessary to search for mechanisms that filter and guide this consumption of information. 
Figure $\mathbf{5}$ - topics of posts received via social networks.

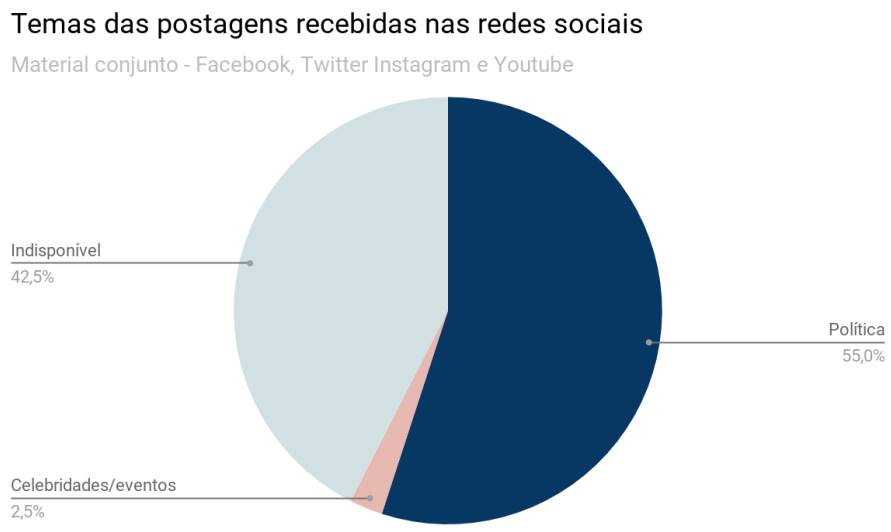

Source: prepared by author (2019).

\subsection{Where the truth originates and what this might reveal}

Out of the 373 links the platform received for verification, 131 were verified to users as "true news". The links came from 34 different input channels, including social networks, blogs and news portals. Despite the diversification of sources, $49.6 \%$ came from three input channels managed by the country's large traditional media conglomerates. Most of the links considered to be "true news" were published on the UOL portal or on platforms associated with the portal, such as JC Online and Congress in Focus. Next, the Verific.ai application then ranked the main input channels which contained true news: the Globo System Gl sites, and the Folha de S. Paulo newspaper website.

UOL accounted for $18.3 \%$ of all true news, as calculated by the Verific.ai application. $G 1$ accounted for $16 \%$ of the total percentage of true news, while Folha de S. Paulo accounted for $7.6 \%$. These three media portals are taken from a list of the 50 most-visited websites in Brazil, according to Amazon Alexa data analytics tool ${ }^{4}$. GI and UOL are also on a list of the sites most used by the Brazilian public between Monday and Friday, according to the 2014 Brazilian Media Survey.

The data reinforce Albert-László Barabási's perspective of outof-scale networks, which proposes that the framework of network connections is completely horizontal. Barabási's model proposes that a small number of nodes are responsible for a large number of connections. Once disconnected, these nodes that function as aggregating hubs would take many others with them (Martino, 2015). "In social networks, 
these kinds of nodes are actors (people, organizations, companies) with a high number of connections. (...) on the internet, they are pages like Google, and major news portals" (p. 80).

Thus, while social networks act as news consumption sites, decentralizing the power that traditional media had gained throughout the twentieth century, the traditional media portals themselves continue to function as hubs for online news consumption. The data cited above, taken from news portals, which are the preferred data input channels for this study as opposed to blogs, are examples of this. This allows us to make inferences about the importance of these sites as active agents in the combat against disinformation, based on strategies such as the Comprova ${ }^{5}$ coalition, created to verify news and rumors during the 2018 election period in Brazil.

On the other hand, the numbers also point out that online traditional media is being contested. In the age of post-truth, hegemony that used to be equated with unquestionable credibility - or at least rarely questioned - is now on par with other information-propagating agents. Just as the number of links received from Facebook can show that this network has been a source of news consumption since 2016 regarding discussions about disinformation, the same argument can be used to show that traditional vehicles like UOL, GI (Globo) and Folha de S. Paulo are also being used by the audience. These vehicles' loss of credibility also subjects the content produced by journalists in these company newsrooms to opposition and criticism.

Out of the 131 links, $63.4 \%$ were sent more than once to the platform, while $36 \%$ was sent only once, which might mean that the platform is subject to double-checking by the audience; i.e., its ability to act could be called into question. The subject that most of the "true news" was reported on related to election poll results. This reinforces how the web has changed the ways in which the public relates to institutions, distrusting more and more the information disclosed by entities such as electoral polling companies or even traditional journalistic media companies.

\subsection{Where false comes from and what this might reveal}

Out of the 373 links received for verification on the platform, 147 were verified to users as "fake news". The links came from 52 different input channels, which shows a greater diversity of input channels than those reported for real news; an increase of $52 \%$ more input channels for false news compared to true news. Unlike true news, 
false news was more spread out in the input channels, but with a greater percentage coming from the platform which sent the most links.

Among all the false news published, $30.6 \%$ was on Facebook. The use of social media for news consumption slowed down or began to slow down in several countries in 2018 , some of the reasons for this are changes to how Facebook is being used and the data distribution scandals associated with said platform which, coupled with the false news analyzed by Verific.ai, reinforces the fact that the consuming public is questioning the information that circulates on Facebook.

In terms of sending links, the results from false news were quite different from the results of true news. Out of the 147 links, $55 \%$ were single uploads, while $45 \%$ of the links were sent at least once to the platform. The numbers, which are in contrast percentage-wise to the logic of true news, show that true news had more requests for multiple tests than false news. In other words, true news, according to the criteria established by the Verific.ai platform, has been challenged more often than the information considered to be false, which reinforces the level of distrust with the press and institutions that support the post-truth era.

\subsection{Something went wrong, now what?}

Out of the number of links that the Verific.ai platform received, $25 \%$ were verified to users as "something went wrong", which means the platform was not able to analyze them. This percentage, which we shall call inconclusive, comes from 36 input channels; representing $38 \%$ of the platform's input news channels. Out of the total number of inconclusive links, 37\% correspond to three input channels. The Leia Já portal was the main one, followed by Facebook and Twitter. This shows the social media messages which were sent to be tested on the platform, which also supports news consumption on these channels and audience interest to measure the level of reliability of the information that they circulate.

Out of the inconclusive links, 10\% were from portals included in the basic list of criteria for trusted sites, indicating a need for the platform to identify factors that may contribute to false-positive or even invalidate verification, as happened in these cases. In contrast, none of the untrustworthy sites were shown in this response category which, coupled with the analysis of false news, shows that the platform was able to provide a minimal response to requests for analyzing untrusted sites.

Out of the links considered inconclusive, 52\% were repeated on the platform and $48 \%$ were single submissions. When comparing 
true and false news data, based on platform criteria, false news had more single links than repeated ones. It is also evident that inconclusive links had a lower double-checking percentage than true news, showing that the concept of truth on social networks and in the post-truth era of communication is being contested.

\subsection{The tortoise and the hare in the post-truth era}

In order to measure the Verific.ai application's capability for verifying information, according to the time it takes to perform the activity, this study compiled data on the verifications performed in seven Brazilian news and/or rumor checking services conducted during the period in which the links in the platform were collected and verified. This proposal does not detract from the human role or the importance of journalists when verifying and checking, but instead shows how important a news link verification tool can be to quickly neutralize the spread of disinformation on the web.

Given the time needed to develop and test the program, and given the current limited capacity for automated context analysis or language identification and ambiguity analysis, we decided to not check politician discourse in this comparison, and instead focus on verifying rumors and/or facts performed by the following services: Comprova, Aos Fatos, Truco, Lupa, Fato ou Fake ${ }^{6}$, Boatos.org ${ }^{7}$ and E-farsas ${ }^{8}$.

According to Figure 6, between October 16 and 28, 162 posts were produced by the vehicles analyzed for this study either confirming or denying some information circulating on the networks. This works out to be an average of 23 checks per vehicle. However, it is important to point out that some of all these verifications repeat rumors/news, since these media act independently from one another and do not necessarily cooperate $100 \%$ of the time. When the analysis is done on a daily basis, it works out to be 13.5 verifications per day for the seven vehicles included in this study, which gives an average of almost two checks per hour.

Consisting of a group of eight Globo System communication vehicles, Fato ou Fake carried out the largest amount of checks within the analysis period. There were 58 checks in total, 35\% of which were carried out by said vehicle. This number does not consider any variables for themes that might cross over into other verifications produced by the group of seven vehicles. The Comprova project, also a joint operation of 24 media outlets in the country, produced 28 verifications over the same period.

Fact-checking agencies, which check politician discourse and 
verify rumors/news at the same time, had a similar production during the analysis period. Aos Fatos produced 23 verifications. Truco, which is part of the Public Agency, verified 21 rumors/news pieces. The Lupa Agency produced 21 rumors/news pieces. Boatos.org conducted 16 verifications, while $E$-farsas verified eight rumors/news pieces.

Between October 16 and 28,2018, Verific.ai received a total of 373 verification links. $80 \%$ of these were single links; i.e., they did not repeat. The single links refer to 132 different rumors/news pieces. As a result, the platform maintained an average of 11 rumors/news pieces checked per day, or two rumors/news pieces per hour. From this framework, one can observe the ability to accelerate the verification process for rumors as part of this mechanism is automatic, and when compared to other methodologies, the application was able to increase the amount of rumors/news verified from two to 16 during the same time period.

However, a different pattern of results is observed between the checks performed by the platform and those produced by said vehicles. Verific.ai receives links automatically and checks all of them. Other services use a selective checking process. This explains why Verific.ai merges more results together when trying to confirm whether certain content is true, while other platforms tend to confirm more false content. It is essential for further research to study the influence of the spontaneous and organic reception of content (Verific.ai model) from the one that pre-selects the content to be verified based on criteria such as dissemination, impact on public debate, and circulation on social networks (this was the case for other vehicles compared in this study), in the pattern of results reported to the public.

Figure 6 - Graph showing rumors/news checked by seven vehicles and Verific.ai.

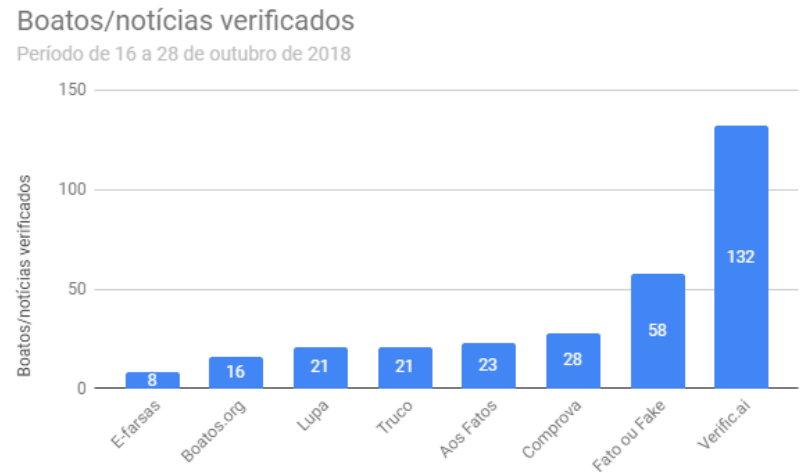

Source: prepared by author (2019). 


\section{Final considerations}

Information has become a strategic resource in society. The changes brought about by the advent of information and communication technologies are driving journalism to reshape itself and innovate from the challenges posed by the post-truth era and the disinformation ecosystem. With weak institutions and the rise of emotions over truth, false news is increasingly influencing public debate. In this context, automated fact-checking tools are beginning to emerge as a way to accelerate the information verification process and offer a more equal race in the fight against disinformation.

This article presents how the Verific.ai platform was developed and how the data it generated, tested during the time period between the first and second round of the 2018 presidential elections in Brazil, can help to understand how news consumption is conducted in the digital environment and to provide insights to overcoming the challenges of automated fact-checking.

Traditional media has been widely questioned by internet news consumers, a movement that used to be hindered by the power and credibility that these media had over the population. At the same time, we can see that channels for accessing online information are fragmented, which includes the increased use of social media, even though the public has difficulty identifying the kind of content that circulates throughout this medium. In the end, we were able to identify that the news which the platform considered true was questioned more than the news considered to be false, which adds to the discussions about the discredit that truth assumes in the information consumption and production ecosystem in the 21 st century.

\section{NOTES}

1 Piauí. (2018) Agência Lupa. Retrieved from: <https://piaui.folha. uol.com.br/lupa/>

2 Pública, A. (2018). Truco. Retrieved from: <https://apublica.org/ checagem/>

3 Fatos, Aos. (2019). Aos Fatos. Retrieved from: <https://aosfatos.org/>

4 Alexa. (2019). Top sites in Brazil. Retrieved from: <https://www. 
5 Comprova, P. (2019) Projeto Comprova. Retrieved from: <https:// projetocomprova.com.br/>

6 G1. (2019). Fato ou fake. Retrieved from <https://gl.globo.com/ fato-ou-fake/>

7 Boatos.org. (2019). Boatos.org. Retrieved from: <https://www. boatos.org/>

8 Lopes, G. (2019). E-farsas. Retrieved from: <http://www.e-farsas.com/>

\section{REFERENCES}

Alsina, M. R., \& Cerqueira da Silva, L. J. (2018). Ética e jornalismo: na era da pós-verdade. Palmas: Revista Observatório, 4 (3), pp. 726-758. DOI: 10.20873/uft.2447-4266.2018v4n3p726

Anderson, C.W., Bell, E., \& Shirky, C. (2013). Jornalismo pós-industrial: adaptação aos novos tempos. São Paulo: Revista de Jornalismo ESPM.

Braga, J. (March 7, 2014). Segundo meio de comunicação mais usado é internet, aponta pesquisa. Retrieved from <http://gl.globo.com/ economia/midia-e-marketing/noticia/2014/03/segundo-meio-decomunicacao-mais-usado-e-internet-aponta-pesquisa.html>

Bell, D. (1977). O advento da sociedade pós-industrial: Uma tentativa de previsão social. São Paulo: Cultrix.

Bendassolli, P. F.; Wood Jr., T., Kirschbaum, C., \& Pina e Cunha, M. (2009). Indústrias criativas: definição, limites e possibilidades. Fórum Indústrias Criativas, definição, limites e possibilidades. São Paulo: v.49. n.1 Retrieved from http://www.scielo.br/pdf/rae/v49n1/v49n1a03.pdf

Castells, M. (2003). A galáxia da internet: reflexões sobre a internet, os negócios e a sociedade. Rio de Janeiro: Zahar.

Castells, M. (2017). A sociedade em Rede. São Paulo: Paz e Terra.

Castells, M. (2017). O poder da comunicação. São Paulo: Paz e Terra.

Ciampaglia, G. L., Prashant Shiralkar, L. M., Rocha, J. B., \& Filippo 
Menczer, A. F. (2015). Correction: Computational Fact Checking from Knowledge Networks. Plos One, [s.l.], v. 10, n. 10, p.1-13. Public Library of Science (PLOS). DOI: 10.1371/journal.pone.0141938

Côrtes, S., Porcaro, R. M., \& Lifschitz, S. (2002). Mineração de dados - funcionalidades, técnicas e abordagens. Rio de Janeiro: PUC, 10 (2). Retrieved from file:///C:/Users/Alice\%20de\%20Souza/ Downloads/02_10_cortes.pdf

D'ancona, M. (2018). Pós-verdade: a nova guerra contra os fatos em tempos de fake news. Barueri: Faro editorial.

Firmo, É. (2018). Reino da trapaça. In I. Filgueiras, P. Bortolotti, É. Firmo, C. Dunker \& D. Muniz. Jornalismo em tempos de pós-verdade. Fortaleza: Dummar. Cap. 3. p. 567-992.

Graves, L. (2018). Understanding the Promise and Limits of Automated Fact-Checking. Oxford: Reuters Institute for the Study of Journalism, 2018. Retrieved from https://reutersinstitute.politics.ox.ac.uk/sites /default/files/2018-02/graves_factsheet_180226\%20FINAL.pdf

Guimarães, A. (2008). Carne e bits: reflexões sobre a indiscernibilidade das fronteiras entre mentes e máquinas e os sistemas cognitivos híbridos (doctoral thesis). São Carlos: Chamber of Deputees online library. Retrieved from <http://bd.camara.gov.br/bd/bitstream/ handle/bdcamara/4545/carne_bits_guimaraes.pdf?sequence=3.>

Gomes, W. (2009). Jornalismo, fatos e interesses. Florianópolis, Insular. Retrieved from <https://drive.google.com/file/d/OB-sk60mWY0MCZT dkYjJmOTItMjJiMC00Yzk3LTg2YzgtZjE3ZDI2MWFmNzQz/view>

Hassan, N., Adair, B., Hamilton, J., Li, C., Tremayne, M., Yang, J., \& Yu, C. (2015). The Quest to Automate Fact-Checking. Texas: University of Texas Arlington. Retrieved from <http://ranger.uta.edu/ cli/ pubs/2015/claimbuster-cj15-hassan.pdf>

Jenkins, H., Green, J., \& Ford, S. (2014). Cultura da Conexão: criando valor e significado por meio da mídia propagável. São Paulo: Aleph.

Kakutani, M. (2018). A morte da verdade: notas sobre a mentira na era Trump. Rio de Janeiro: Intrínseca.

Keyes, R. (2018). A era da pós-verdade: desonestidade e enganação na vida contemporânea. Petrópolis: Vozes. 
Kovach, B., \& Rosenstiel, T. (2003). Os elementos do jornalismo: o que os jornalistas devem saber e o público exigir. São Paulo: Geração Editorial.

Kumar, K. (1997). Da sociedade pós-industrial à pós-moderna: novas teorias sobre o mundo contemporâneo. Rio de Janeiro: Jorge Zahar.

Lage, N. (2006). Linguagem jornalística. São Paulo: Ática.

Lazer, D. M., Baum, M. A., Benkler, Y., Berinsky, A. J., Greenhill, K. M., Menczer, F., Metzger, M. J., Nyhan, B., Pennycook, G., Rothschild, D., Schudson, M., Sloman, S. A., Sunstein, C. R., Thorson, E. A., Watts, D. J., \& Zittrain, J. L. (2018). The science of fake news. Science, [s.I.], v. 359, n. 6380, p.1094-1096, 8 mar. 2018. American Association for the Advancement of Science (AAAS). DOI: 10.1126/science.aao2998

Lemos , A, \& Lévy, P. (2010). O futuro da internet: em direção a uma ciberdemocracia planetária. São Paulo: Paulus.

Lévy, P. (1998). Inteligência coletiva: por uma antropologia do ciberrespaço. São Paulo: Loyola.

Lévy, P. (1999). Cibercultura. São Paulo: Ed. 34.

Martino, L. M. S. (2015). Teorias das mídias digitais: linguagens, ambientes, redes. Petrópolis: Vozes.

Neisser, F. G. (2015). Fact-checking e o controle da propaganda eleitoral. Ballot, [s.I.], 1 (2), pp. 178-212. DOI: 10.12957/ballot.2015.22133

Newman, N., Fletcher, R., Kalogeropoulos, A., Levy, D. A., \& Nielsen, R. K. (2018). Reuters Institute Digital News Reporte 2018 . Oxford: Reuters Institute, 2018. Retrieved from http://media.digitalnewsreport.org/ wp-content/uploads/2018/06/digital-news-report-2018.pdf?x89475

Nielsen, R. K., \& Graves, L. (2017). "News you don't believe": audience perspectives on fake news. Oxford: Reuters Institute for the Study of Journalism. Retrieved from <https://reutersinstitute. politics.ox.ac.uk/sites/default/files/2017-10/Nielsen\%26Graves_ factsheet_1710v3_FINAL_download.pdf>

JORNAL, R. (Oct. 23, 2018). Estudante pernambucana cria aplicativo para identificar fake news. Retrieved from: <https://radiojornal.ne 10. uol.com.br/noticia/2018/10/23/estudante-pernambucana-criaaplicativo-para-identificar-fake-news-61706> 
Recuero, R. (2012). As Redes Sociais na Internet e a Conversação em Rede. Alagoas: Ciseco. Retrieved from <http://www.raquelrecuero. com/ciseco.pdf>

Rodrigues, L., \& Hennigen, I. (2011). Jornalismo, a questão da verdade e a produção de subjetividade. Rio de Janeiro: Arquivos Brasileiros de Psicologia, 63(3). Retrieved from <http://pepsic.bvsalud.org/scielo. php?script=sci_arttext\&pid=S1809-5267201 1000400005>

Sanhueza, P. M. (2017). Medios de comunicación y posverdad: Análisis de las noticias falsas en elecciones presidenciales de EE.UU de 2016 (master thesis). Barcelona: Universidad Autónoma de Barcelona. Retrieved from <https://ddd.uab.cat/pub/trerecpro/2017/hdl_207 2_293813/TFM_Priscilla_Munoz.pdf>

Santaella, L. (2003). Culturas e artes do pós-humano: da cultura das mídias à cibercultura. São Paulo: Paulus.

Santaella, L. (2013). Intersubjetividade nas redes digitais: repercussões na educação. In A. Primo (Org.). Interações em Rede. Porto Alegre: Sulina. Cap. 2. p. 33-47.

Santaella, L. (2018). A pós-verdade é verdadeira ou falsa? Barueri: Estação das Letras e Cores.

Shirky, C. (2011). A cultura da participação: criatividade e generosidade no mundo conectado. Rio de Janeiro: Zahar.

Toffler, A. (1995). A terceira onda. 20. Ed. Rio de Janeiro: Record.

Tomaél, M. I., Catarino, M. E., Valentim, M.L., Almeida Jr, O. F., Silva, T. E., Alcará, A. R., Selmini, D., Montanari, F. R., Yamamoto, S., \& Almeida, C. C. (2009). Avaliação de fontes de informação na internet: critérios de qualidade. Brapci. Retrieved from<http://www.brapci.inf.br/index.php/ article/view/0000001061/a9f7ed402ee5bd 1 ff45ead513a74e0cb>

Traquina, N. (2005). Teorias do jornalismo: porque as notícias são como são. Florianópolis: Insular.

Traquina, N. (2008). Teorias do jornalismo: a tribo jornalística - uma comunidade interpretativa transnacional. Florianópolis: Insular.

Wardle, C. (2017, Março 14). Noticias falsas. Es complicado. First Draw. Retrieved from https://es.firstdraftnews.org/2017/03/14/ noticias-falsas-es-complicado/ 
Zattar, M. (2017). Competência em informação e desinformação: critérios de avaliação do conteúdo das fontes de informação | Information literacy and disinformation. Liinc em Revista, [s.I.], 13 (2), p.285-293. DOI: 10.18617/liinc.v13i2.4075

Zommer, L. (2015). El boom del fact checking y la vuelta a las fuentes. In G. Roitberg, \& F. Piccato. Periodismo disruptivo. Dilemas y estrategias para la innovación. Buenos Aires: La Crujía Ediciones.

DARIO BRITO ROCHA JÚNIOR. PhD in Information Design from the Federal University of Pernambuco (2017) and a Master's Degree in Letters / Linguistics from the Federal University of Pernambuco (2015). Professor of undergraduate courses in Journalism, Digital Games and Photography at the Catholic University of Pernambuco and undergraduate and postgraduate programs in Fashion Design at Senac College and the Mauricio de Nassau University Center. E-mail: dariobrito@gmail.com.

\section{ANTHONY JOSÉ DA CUNHA CARNEIRO LINS.}

PhD in Biotechnology from the Renorbio program (2018), in connection with the Federal Rural University of Pernambuco (UFRPE) and a Master's Degree in Computer Engineering, specializing in Intelligent Computing, from the Polytechnic School at the University of Pernambuco (2012). Professor and researcher at the Catholic University of Pernambuco (Unicap) in the fields of Digital Games, Creative Industries and Environmental Processes. E-mail: thonylins@gmail.com.

\section{ALICE CRISTINY FERREIRA DE SOUZA.} Master's Degree in Creative Industries from the Catholic University of Pernambuco (2018) and a postgraduate degree in Human Rights from the Catholic University of Pernambuco (2013). Graduated in Journalism from the Catholic 
University of Pernambuco (2011) and is a member of Red de Jóvenes Periodistas Dististas Latitudes. E-mail: alicecristiny@gmail.com.

LUIZ FELIPE DE OLIVEIRA LIBÓRIO. Master's Degree in Computer Science from the Federal University of Pernambuco (2016) and graduated in Computer Science from the Federal University of Pernambuco (2011). Works in software development as a full-stack developer, developing Web systems in PHP and Python. E-mail: Ifliborio@gmail.com.

\section{ANDRÉ HENRIQUE DE BRITO LEITÃO.} Graduated in Computer Science from the Catholic University of Pernambuco (2011) and is a software development technician from the Brazilian Union of Technology (2005). Develops research on how to use technology to facilitate the teaching of math to children, electronic games and bioengineering. E-mail: andrehbleitao@gmail.com.

FLÁVIO HENRIQUE SOUZA SANTOS. Master's Degree in Environmental Process Development from the Catholic University of Pernambuco (2015), graduated in Information Systems from Joaquim Nabuco College (2012) and is a graduate in Social Communication from the Catholic University of Pernambuco (2004). E-mail:flaviohssantos@gmail.com. 